\title{
Systematic Management Mode of the State-Run Silk-Weaving Industry of the Song Dynasty
}

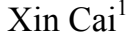 \\ ${ }^{1}$ College of Fashion \& Art Design, Donghua University, Shanghai, China \\ Correspondence: Xin Cai, College of Fashion \& Art Design, Donghua University, Shanghai, China. E-mail: \\ vivixincai@sina.com
}

Received: January 14, 2015 Accepted: February 3, 2015 Online Published: April 2, 2015

doi:10.5539/ass.v11n9p333 URL: http://dx.doi.org/10.5539/ass.v11n9p333

\begin{abstract}
Based on abundant documents evidences, this paper analyzes the systematic management mode of the state-run silk-weaving industry in China of the Song dynasty. The obvious systematic characteristics can be described as distribution, division and operation. The state-run silk-weaving industry is widely distributed in the capital city and the areas where sericulture and silk weaving are already highly developed. It is clearly divided into weaving, dyeing, embroidering, clothing producing and silk articles manufacturing. The state-run silk-weaving industry had the privilege to employ highly skillful craftsmen. The supervisors, designated by the government, controlled the manufacturing process and the quality and quantity of the products. The study shows that, on the basis of thousands of years accumulation, the state-run silk-weaving industry of the Song dynasty presented the all-round development in ancient China, offering a reference for the Yuan, the Ming and the Qing dynasty.
\end{abstract}

Keywords: management mode, the Song dynasty, the state-run silk-weaving industry, systematic

\section{Introduction}

The state-run silk-weaving industry in the Song dynasty produced specialized noncommercial silk fabric livelihoods for the state and the ruling class. Highly centralized feudal autocratic empire pushed systematic management mode in this industry. A series of state-run weaving organizations for different divisions were set up in the capital city as well as local places by the central government. These organizations, were supervised and abolished by the central government. The local governments set up the same organizations as well. Different scales of state-run weaving organizations were widely spread in Hebei, Shandong, Zhejiang, Sichuan and other silk producing areas at the beginning of the Song. According to the diverse requirements of the state and consumers, the government set up workshops producing varieties of silk fabrics, and specialized agencies engaging in weaving, dyeing, sewing, embroidery, and silk articles manufacturing. They issued instructions concerning the number of staff and quotas of output to these plants.

Compared with the Tang dynasty, the state-run weaving industry in the Song was advanced in distribution, division of labor and the management system owing to the advancements in agriculture, transportation, trade and textile technology. In order to guarantee the materials supply in the capital city, canal transportation (cao-yun) was particularly well developed in the Song, which led to the prosperity of handicraft industry in different cities. Chinese traditional feudal natural economy made weaving industry separate from farming completely in the Song. The harvest of agricultural products promoted the development of commodity economy. All these contributed to the surplus of raw materials to be sold and labor to be hired in the nongovernmental market. The appearance of the Treadle-Operated Silk Reeling frame (jiao-ta sao-che), the adoption of the method of warping on frame (zhou-jia zheng-jing fa) and the creation of the String-Heddle Patterning loom (shu-zong ti-hua-ji) achieved higher production efficiency and better product quality.

\section{Distribution of State-Run Silk-Weaving Industry of the Song}

The state-run silk weaving organizations were mainly spread in the capital city, Hebei, Shandong, Zhejiang, Sichuan and other areas where sericulture and silk industry were highly developed.

\subsection{Silk-Weaving Plants in the Capital Cities Established by the Central Government}

In the Northern Song, a series of weaving, dyeing, embroidery, manufacturing state-run weaving plants were already established in the capital city Bianjing (modern Kaifeng). Along with the moving south process of the 
court, most plants also moved to Lin'an (modern Hangzhou). In 1131, the Bureau of Weaving and Sewing (ling-jin yuan) and the Bureau of Fine Crafts (wen-si yuan) still existed (Song, during, A. D. 1796-1820).The textile historian, Professor Yuan Xuanping thinks that the state-run dyeing plants were likely to have existed until Emperor Gaozong's Shaoxing reign period (A.D.1131 1162) (Xuanping \& Feng, 2009).

\subsection{Silk-Weaving Plants outside the Capital Cities Established by the Central Government}

The state-run silk-weaving plants set up by the central government were widely distributed outside the capital. The plants in the Western Capital (modern Luoyang), Ordinary Prefectures of Zhen, Ding, Qing, Yi and Zi mainly produced polychrome compound warp-faced tabby or twill (jin), tabby with pattern in twill (qi), lu-tai (silk fabric with pattern like deer fetus, usually made by clamp-resist dyeing) and tou-bei (probably one kind of silk fabric has similar appearances on face and back ). There were the Offices of Gauze Weaving (zhi-luo wu) in the Superior Prefecture of Jiangning and the Ordinary Prefecture of Run, the Workshop of Damask (ling-qi chang) in the Ordinary Prefecture of $\mathrm{Zi}$, while office in the Ordinary Prefecture of Bo purchased plain silk gauze with crepe (zhou-sha) and office in the Superior Prefecture of Daming wove silk tabby with crepe (zhou-hu). The Ordinary Prefectures of Qing, Qi, Yun, Pu, Zi, Wei, Yi, Mi, Deng, Lai, Heng, Yong, Quan purchased sparsely woven silk (ping-shi) $\cdots \cdots \cdot$ used for clothing and granting rewards at the Chinese Lunar New Year (Tuo, et al. A D. 1346). There are the same contents and more specific records in General history of institutions and critical examination of documents (Wenxian tongkao, Vol. 20, p. 195).Though there was no specific time for the quotation, it should be records relevant to the state-run textile organizations from 1018 to 1059, according to the analysis of historian Xu Dongsheng specialized in the study of the Song (Dongsheng, 2012). Among the organizations mentioned, there were some mills producing silks, and some offices taking charge of silk products collection and purchase for governments. Bureau of purchase (shi-mai yuan) in the Ordinary Prefecture of Yi wove refined silk twill (shu-se ling), and the Ordinary Prefectures of Peng, Jin, Han, Qiong, Shu, Mei, Ling, Jian, Sui, $\mathrm{Zi}$, Rong, Pu, and the Military Prefecture of Huai' an wove all sizes of plain weave silks, qizheng (probably one kind of silk fabric with qizheng pattern), wefts backed silk twill (hua-ling) (Duanlin, A. D. 1314). In the Northern Song, the central government set up state-run silk-weaving plants in Hebei, Shandong, Zhejiang, Sichuan and other areas, while in the Southern Song, the plants were mainly set up in Sichuan and Zhejiang areas. These plants produced different kinds of silk products, mostly local specialties. There were specific information about such plants' abolition in historical documents. The Office of Damask Weaving (zhi-ling wu) in the Ordinary Prefecture of Hu was abolished in 982 (Song, during, A.D.1796-1820). The Office of Weaving and Sewing (ling- jin wu) in the Ordinary Prefecture of Tan was abolished in 993 (Duanlin, A. D. 1314). The imperial edict concerning the establishment of contexture chamber in the Ordinary Prefecture of Hang was issued in 995 (Song, during A. D. 1796-1820). The Office of Gauze Weaving (zhi-luo wu) in the Ordinary Prefecture of Chang was abolished in 999 (Song, during A. D. 1796-1820).

\subsection{Silk-Weaving Plants outside the Capital Cities Established by the Local Governments}

Outside the capital city, Jin Institute of the Superior Prefecture of Chengdu (Chengdu jin-yuan) was the most important state-run silk-weaving plant and it was the single most significant plant set up by local governments. Lv Dafang started to build Jin Institute in the east of prefectural government (Zhu, the Yuan dynasty). In the Southern Song, the intension on the border of the north minorities' regimes and the Song gave rise to conflicts. Later, the Song lost a series of wars, and only half of the country territory remained. In order to buy horses conveniently to strengthen military and defend the nation, the General office of trade in horse and tea ( $d u-d a t i-j u$ cha-ma-si), the agency originally in charge of exchanging tea into horses began weaving polychrome compound warp-faced tabby or twill, damask, bedding, with which, it could get horses for barter in the Ordinary Prefecture of Li. These silk products were produced in the plants in Yingtian Temple, Northern Temple (bei chan-si), Luyuan Temple. In 1168, Jin Institute in General office of trade in horse and tea and the Superior Prefecture of Chengdu were combined into a larger state-run silk-weaving unit producing high quality silk products (Zhu, the Yuan dynasty). Though these products circulated through the means of exchange, they still could not be regarded as commodities in the true sense due to the reason that the exchange income was only for national defense.

During the reign of Emperor Zhenzong, governmental Bureau of Dyeing (guan ran yuan) once was set in Chengdu (Ke, the Southern Song dynasty). Because of insufficient detailed records, it's hard to figure out what state-run silk-weaving plant it was affiliated with.

\section{Division of State-Run Silk-Weaving Industry of the Song}

Local silk products were the main products of the state-run silk-weaving plants distributed in different areas. These areas produced silk twill (ling), silk gauze (luo), polychrome compound warp-faced tabby or twill (jin), 
tabby with pattern in twill ( $q i)$, plain weave silk (juan), plain silk gauze or silk open tabby (sha), sparsely woven silk (shi), according to the division of abundant fabrics in the Song.

\subsection{Division of State-Run Silk-Weaving Industry of the Northern Song}

Not only garments, but also silk products were produced in the state-run silk-weaving plants set up by the central government in the capital. In general, we can learn of the basic facts of the state-run silk-weaving industry chain at that time through the process silk product production and the division of products type. Some of the plants were engaged in dyeing, embroidery, apparel and other parts, and others were engaged in manufacturing emperor's home textiles, imperial edict (guan-gao), official certificate for monk or nun (du-die), and silk products for other special purposes. The following table 1 illustrates the basic information of each plant.

Table 1. Basic Information of State-run Silk-weaving Plants in the Northern Song

Names of plants
The Office of Weaving and
Sewing(ling-jin wu)/Inner Palace
Weaving Office (nei ling yuan)
(Song, during A. D. 1796-1820)
The Bureau of Apparel (cai-zao
yuan) (Song, during A. D.
1796-1820)
The Bureau of Apparel (cai-zao
yuan) (Song, during A. D.
1796-1820)
The Bureau of Apparel (cai-zao
yuan) (Song, during A. D.
1796-1820)
The Bureau of Fine Crafts (wen-si
yuan) (Song, during A. D.
1796-1820)

The East Bureau of Dyeing for Inner Palace (dong nei ran yuan) (Song, during A. D. 1796-1820)

The West Bureau of Dyeing for Inner Palace (xi nei ran yuan) (Song, during A. D. 1796-1820)

The West Bureau of Dyeing ( $x i$ ran-se yuan) (Song, during A. D. 1796-1820)

The Rear Park Workshop Western Capital Workshop (hou-yuan zuo $x i$ zuo) (Song, during A. D. 1796-1820)

The Office of Embroidery (wen-xiu yuan) (Song, during A. D. 1796-1820)

Founding Time Responsibilities

A. D. 966 (Song, during A. Weaving exquisite silk, sewing, making

D. 1796-1820) embroidery for carriages and accessories (Duanlin, A. D. 1314)

A. D. 966 (Song, during A. Tailoring clothes for the use by state, D. 1796-1820) initially (Song, during A. D. 1796-1820)

A. D. 1010 (Song, during Patrolling, managing government property A. D. 1796-1820) (Song, during A. D. 1796-1820)

A. D. 1012 (Song, during Undertaking home textile and embroidery A. D. 1796-1820) (Song, during A. D. 1796-1820)

A. D. 979 (Song, during A. Controlling things for carriages, sedan D. 1796-1820) chairs, royal seal, ritual apparatus and costumes; the lower department managed production of ling, jin, and weaved imperial edict (guan-gao) and official permit to become a monk (nun) and join a monastery (du-die) (Song, during A. D. 1796-1820)

A. D. 978 (Song, during A. Dyeing silk, string, leather (Song, during A. D. 1796-1820)

D. 1796-1820)

A. D. 978 (Song, during A. D. 1796-1820)

Dyeing silk, string, leather (Song, during A. D. 1796-1820)

A. D. 977 (Song, during A. D. 1796-1820)

Controlling dye for dyeing plants (ran-yuan) (Song, during A. D. 1796-1820)

Earlier than A. D. 1000 Manufacturing the forbidden clothing (Song, during A. D. textiles (Song, during A. D. 1796-1820) 1796-1820)

A. D. 1104 (Song, during Weaving and making embroidery for royal A. D. 1796-1820) carriages, clothing and sacrificial ceremony (Duanlin, A. D. 1314) 
The Bureau of Apparel (cai-zao yuan) was once in a short time in charge of patrolling during the process of transforming from manufacturing clothes to manufacture home textiles and embroidery. The job of manufacturing clothes and accessories was mostly undertaken by the Bureau of Fine Crafts (wen-si yuan). The plants took charge of manufacturing clothing and home textiles were not explicitly separated by the government until the Southern Song.

The Office of Embroidery (wen-xiu yuan), a department specialized in embroidery, was set up late. In the process of making embroidery, the tools needed were simple and small. Having no needs to gather the workers together, the Office of Embroidery just provided samples to them. Perhaps this is the technical reason that explain why the Office of Embroidery was set up late.

\subsection{Division of State-Run Silk-Weaving Industry of the Southern Song}

After moving the capital to Lin'an, there were many state-run silk-weaving plants in the capital city (Pingsheng \& Jinfang, 2014). The division of the state-run silk-weaving plants became clearer. For instance, on the basis of the Bureau of Apparel (cai-zao yuan), the clothing and home textiles departments were separated, so the Office of Emperor's Costume (yu-fu suo) and the Office of Emperor's Home Textiles (guo-yu suo) were established. Take the Bureau of Fine Crafts (wen-si yuan ) for example, many workshops once affiliated with it became independent and were upgraded and renamed (Zimu, A. D. 1274). One of them was the Workshop of Silk Shoes $(s i-x i e z u o$ ), and it was renamed as the Bureau of Silk shoes (si-xie ju) in Emperor Gaozong reign period (A. D. 1127-1162), specializing in providing royal silk shoes (You, during A. D. 1195-1200). Other workshops were the Office of Silk (si-bo suo), the Office of Girdle (yao-dai suo), the Office of Weaving and Dyeing (zhi-ran suo), etc (You, during A. D. 1195-1200).

\section{Personnel Management of State-Run Silk-Weaving Industry of the Song}

The state-run plant workers in the Song were mainly hired craftsmen (mu-jiang), who were hired to sell their labor and got paid, and they had personal freedom nominally. Compared with other handicraft industry workshops, state-run silk-weaving plants only employed hired craftsmen (mu-jiang) obeying the strict personnel quota. Some of them even had more workers than shipyards. During Emperor Gaozong's Shaoxing reign period (A. D. 1131-1162) in the Southern Song, each shipyard in the Ordinary Prefectures of Hong, Ji and Gan only had 200 workers including labors and soldiers (Song, during A. D. 1796-1820). After Emperor Xiaozong's Qiandao reign period (A. D. 1165-1173), the total number of shipping craftsmen was only 280 (Cong, 1169\&E, during A. D. 1241-1251), far less than that of Contexture Chamber (zhi-shi) in the Ordinary Prefecture of Hang of Emperor Huizong reign period (A. D. 1100-1126) (Yufeng, 2012). When the Bureau of Embroidery (wen-xiu yuan) was founded, there were 300 workers, and the number of workers in Jin Institute of the Superior Prefecture of Chengdu (Chengdu jin-yuan) in the Southern Song was more than 1000.

\subsection{Sources of Craftsmen}

Some outstanding craftsmen were selected from the commoners. During the establishment of the Bureau of Embroidery (wen-xiu yuan), three hundred experienced embroiderers, were recruited by the governments from all regions as workers (Song, during A. D. 1796-1820), many of them were military craftsman (jun-jiang). Before the formal establishment of Jin Institute of the Superior Prefecture of Chengdu (Chengdu jin-yuan), the previous institute was required to provide a certain number of Jin to the Royal Court, so Jin Institute paid materials and salary in advance to family workshops, but their products were unsatisfactory and the quantity was inadequate. Later on, Jin Institute began to appoint military craftsman (jun-jiang) to fulfill this task. And it finally chose military craftsman (jun-jiang) because their work turned out to be much more exquisite and they used less materials than the former workers (Song, during A. D. 1796-1820). There were mainly imperial guard (jin-jun) for combating and national army (xiang-jun) as laborers among the large number of troops in the Song. In national army (xiang-jun), there were justifiable craftsmen. Although the military systems were different between the Northern Song and Southern Song, it occurred during both dynasties that imperial guard (jin-jun) were engaged in silk-weaving industry, and the total number of soldiers was huge and the working time was extremely long. During Emperor Qinzong's Jingkang reign period (A. D. 1125-1127) in the Northern Song (Song, during A. D. 1796-1820) and during Gaozong's Shaoxing reign period (A. D. 1131-1162) in the Southern Song (Xinchuan, ca.1261), it was disclosed that the managers of imperial guard (jin-jun) had stopped the military training and turned the troop into craftsmen to produce exquisite silk products, which was illegal, but it was commonly seen and existed for a long time. Ultimately, the excellent working skills and easy management, made the military craftsman (jun-jiang) ideal workers. 


\subsection{Labor Intensity of Craftsmen}

Craftsmen in the state-run silk-weaving plants worked efficiently. Eighty military craftsman (jun-jiang) wove Jin made of sufficient materials and by the finest method (da-liao xi-fa jin) and tou-bei (probably one kind of silk fabric has similar appearances on face and back) over 730 bolts, and it was on record (Tao, during A. D. 1029-1102). Based on that historical document about Jin Institute of the Superior Prefecture of Chengdu (Chengdu jin-yuan), the following analysis and deduction could be made: The study assumes annual output of Jin Institute of the Superior Prefecture of Chengdu (Chengdu jin-yuan) in the Song was 736 bolts, and the total length of Jin was $8 * 736=5888$ meters(during Emperor Gaozong's Shaoxing reign period (A. D. 1131-1162), one bolt of Jin was 8 meters long) (Song, during A. D. 1796-1820).

The average length of Jin wove by one military craftsman (jun-jiang) for one year was 5888/0.8=73.6 meters.

The average length of Jin wove by one military craftsman (jun-jiang) for one day was 73.6/365 $=0.2$ meters.

Today, in most cases, one skillful weaver can weave 0.12 meter of Jin using traditional loom 8 hours in one day (depending on the technique of making different motifs) (the author was informed the data from a practice research in Shu brocade Institute, Chengdu, Sichuan, China, in the spring of 2007).

\subsection{Remuneration for Craftsmen}

The production efficiency of textile craftsmen in the Song is nearly 1.7 times that of nowadays' artisans, and they were paid decently by the government. The salary was on the higher level in the whole state-run handicraft industry, higher than that of those who worked for mint or worked in the construction field. In 971, the fourth year of Emperor Taizu's Kaibao reign period (A. D. 968-976), female workers of the Bureau of Weaving and Sewing (ling-jin yuan) were paid 2 dan(there was a series of units of volume in ancient China, 10 sheng equal 1 dou and 10 dou equal to 1 dan) grain, and 6 dou rice bean per month (Song, during, A. D. 1796-1820), that was about 8.6 sheng of food per day, while the workers who worked for mint in every Superior Prefecture and Ordinary Prefecture were only paid by 193 wen (a unit of currency in ancient China) and 2 sheng of rice per day (Song, during A. D. 1796-1820). The workers building walls were paid by 350 wen and 2.5 sheng of rice per day in the Superior Prefecture of Lin'an during Emperor Gaozong's Shaoxing reign period (A. D. 1131-1162) (Song, during A. D. 1796-1820). In the Southern Song, when the purchase power of money had shrunk a lot owing to inflation, the salary paid by means of foods was comparable. Comparatively speaking, it was quite good that textile workers could get so much food every day, which reflected the fact that the ruling class attached great importance to the state-run silk-weaving industry and their great need for exquisite silk products.

\section{Manufacturing Supervision of the State-Run Silk-Weaving Industry of the Song}

In the state-run silk-weaving plants, there were staff members specializing in supervising and assisting producing. There were officers, functionaries and workers who played different roles and took different responsibilities. In 999, one administrative official, one Sanban Envoy and 17 beadles in the East Dye House (dong ran-se ku) were designated to supervise and assist the producing process in the plant (Song, during A. D. 1796-1820). In 1187, there were lay offs in both upper and lower departments. For the lower department, consumption note taker (ku-jing si), materials tabulator (hua-liao si), entrance guard (men-si), materials weigher (chen-zi), storage inspector (ku-zi) were involved (Song, during A. D. 1796-1820). At the beginning of Jin Institute's establishment, the membership system called $h u$-tou was adopted, it was to add managerial personnel between the officers and craftsmen. In the year of 971(the fourth year of Emperor Taizu's Kaibao reign period (A. D. 968-976)), the membership system was abolished due to its redundant numbers, highly salary and irresponsibility which became barriers to production. And after that, production was stimulated by officers managing craftsmen directly and the increased payments (Song, during A. D. 1796-1820).

\subsection{Materials Control}

The government guaranteed the application and use of materials of these plants. In 1187, (the fourteenth year of Emperor Xiaozong's Chunxi reign period (A. D. 1174-1189)), the Bureau of Fine Crafts (wen-si yuan) made a budget of materials consumption and annual output of weaving 1800 bolts (pi) of ling one year needs silk over 35000 liang (ounce). The Ministry of Revenue ( $h u-b u$ ) would provide 15000 or 20000 liang (ounce) raw silk. When it came to ceremonies or the award from the emperor for merits and honor, additional raw silk could be applied (Song, during A. D. 1796-1820). The Ministry of Revenue ( $h u-b u)$ in feudal China also took necessary methods in case of the materials' loss, waste, even use for other purposes. In the third Chinese lunar month of 971 (the fourth year of Emperor Taizu's Kaibao reign period (A. D. 968-976)), the Bureau of Weaving and Sewing (ling-jin yuan) asked craftsmen to dye the silk on the spot, reducing $0.5 \mathrm{Kg}$ dye per bolt to inspect the usage of dye. If they found that the color was brighter than before, they registered the dye consumption 
according to season and reported it to the central government to count the quantity of receipt and consumption every year (Song, during A. D. 1796-1820). The registration was recorded as a list of everything that happened, i.e, in the eleventh Chinese lunar month of 1018, monthly record of the Bureau of Weaving and Sewing (ling-jin yuan), the exact starting time and ending time, exact number, size and weight of products and other details were carefully recorded (Song, during A. D. 1796-1820). Meanwhile, the necessary labor time of all productions were explicitly stipulated. The Office of Gauze Weaving (zhi-luo wu) in the Ordinary Prefecture of Run, as mentioned before, clarified that every twelve days, one craftsman should finish one bolt ( $p i$ ) of gauze (Song, during A. D. 1796-1820).

\subsection{Output Control}

The state-run handicraft industry in the Song had specific provision on profits, output, and quality, according to the plan. The profits of state-run silk-weaving plant purely belonged to the government, accordingly, the provision was much stricter. The production plan and product structure could be adjusted according to the requirement of the state. In the first lunar month of 1027, the Secretariat- Chancellery (zhong-shu men-xia) reported to the emperor that in the Ordinary Prefectures of $\mathrm{Yi}, \mathrm{Zi}$ in the Circuit of Xichuan, the total annual output of ling of raw, refined, yellow, white, and different sizes, and figured silk open tabby (hua-sha) would be the same, and polychrome compound warp-faced tabby or twill (jin), tabby with pattern in twill (qi), lu-tai (silk fabric with pattern like deer fetus, usually made by clamp-resist dyeing), tou-bei duan-zi (probably one kind of satin has similar appearances on face and back), qizheng (probably one kind of silk fabric with pattern entitled qizheng) reduced by half. They reduced the annual production plan and produced ordinary products in the hope of meeting the need of the state at that time (Song, during A. D. 1796-1820). In the fifth lunar month of 1135 , because of the lack of craftsmen in the Bureau of Fine Crafts (wen-si yuan), the materials of ling for imperial edict and official permit for monks or nuns and join a monastery (guan-gao du-die ling) for those whose official rank were under four was altered. When the materials were quite scarce, the Ministry of Works in feudal China (gong-bu) would ask the local Fiscal Offices to arrange weaving, increasing 20000 bolts ( $p i$ ) in addition to 100000 bolts (pi), and deliver it inch by inch and it would be carried out in autumn (Song, during A. D. 1796-1820) It's an example of delivering product arrangement to the local plants according to the state needs. Jin Institute of the Superior Prefecture of Chengdu (Chengdu jin-yuan) was designated an annual task of Jin for tribute, Jin for imperial edict (guan-gao jin), padded jackets for civil officials' and military officers (chen-liao $a o-z i$ ), and Guang-xi Jin altogether 690 bolts (pi) in the Northern Song, after the Battle of Dujiang, that number was raised nine times (Zhu, the Yuan dynasty). The government assigned the task to such official workshops with an annual output one year in advance.

\subsection{Quality Control}

The state-run silk-weaving plants were strict with products. They usually had formulaic style, so that the ruling class could indentify identities according to the styles and colors of garments. From textiles for carriages, clothes to sacrifice offerings, all of them were in certain styles respectively (Song, during A. D. 1796-1820). The supervision organizations set up by the central government was efficient. In 1026, the imperial edict was written to ban the illegal producing of diverse pattern fabrics and styles of emperor's clothes samples in the Bureau of Weaving and Sewing (ling-jin yuan). Severe punishment would be imposed on (Song, during A. D. 1796-1820). Because of the advantage in manpower and resources, the products were of the best quality. So they were marked as a symbol of reaching high quality standard, and preventing fake as well. There was Made by the Bureau of Fine Crafts (wen-si yuan) on imperial edict for civil officials and military officers (gao-shen) and official permit for monks or nuns and join a monastery (du-die) (Song, during A. D. 1796-1820).

\section{Historical Status of the State-Run Silk-Weaving Industry of the Song}

The Song dynasty is an important period in the development of Chinese state-run silk-weaving industry. Systematization in distribution, division, and institutional system, had made a historic breakthrough. Actually, its achievements benefited from the prosperity of nongovernmental silk weaving industry. In the Northern Song, in a certain year, the nongovernmental output of plain weave silk had reached 5382709 bolts ( $p i)$, silk wadding, hand knitting yarn had reached 13852797 liang (ounce) (Song, during A. D. 1796-1820). In the Song, nongovernmental silk-weaving industry developed exponentially, and the number of family workshops all over the country reached at least 100000 (Xia, 2009). A conclusion based on reports in The treaties on the nine regions during the Yuanfeng (A. D. 1078-1085) period (Yuanfeng jiuyu zhi) is that there were 128 prefectures produced silk. The state-run silk-weaving plant had preferential access to raw materials and they hired skillful craftsmen as their employees to manufacture high-grade silk articles. 
The Contexture Chamber, Dye Chamber and local official plants for apparel were set up in Chinese state-run silk-weaving industry from the Han dynasty. In the Tang, they developed the Bureau of Weaving and Dyeing (zhi-ran shu), the Bureau of Handicrafts (shang-gong ju), the Bureau of the Concubine Palace (ye-ting ju) for the royal, and the Workshop of Weaving and Sewing (ling-jin fang) for the commoner. The workshop of Weaving an Sewing (zhi-ren zuo), the Workshop for Manufacturing Figured Ribbon (zu-shou zuo), the Workshop of Manufacturing String (chou-xian zuo), the Workshop of Refining and Dyeing (lian-ran zuo), including the Bureau of Weaving and Dyeing (zhi-ran shu), had a certain degree of labor division, and among them the workshop of Weaving and Sewing (zhi-ren zuo) took the responsibility of producing sparsely woven silk (shi), plain silk gauze or silk open tabby (sha), silk gauze (luo), polychrome compound warp-faced tabby or twill (jin), tabby with pattern in twill (qi), etc. The state-run silk-weaving industry in the Tang could barely expand the capacity of its layout. In the Song, the arrangement was balanced, making full use of regional resource, providing a reference for state-run silk-weaving plants' distribution in the Yuan and the Ming dynasty. In terms of affiliation, there were plants founded by the central and the local governments. The local governments were in charge of the local plants, which also provided a reference for the Yuan and the Ming dynasty state-run silk-weaving plant establishment. In the Yuan, the central government set up plants in charge of weaving exquisite silk featuring emperor's motifs, golden brocade (Nasisher) and other royal fabrics in the capital, like the Office of Manufacturing Royal Silk (shan-gong si), Huns' northern capital Bureau (Beshbalyq-ju), etc. Meanwhile, the central government set up many plants of weaving and dyeing in the northern inland areas, the local governments set up agencies of weaving and dyeing according to their own conditions. In the Ming, there were six plants of weaving and dyeing set up by the central government. Twenty three agencies of weaving and dyeing set up by the local governments and spread over seven provinces. The former six plants only could be seen in the two capitals, Nanjing and Beijing, which was different from other dynasties (Jinmin, 1990).

The employment system adopted in the state-run manufacturing industry run thoroughly in the silk industry. Compared with labor craftsmen who did shift work (fan-jiang) in the Tang, hired craftsmen (mu-jiang) owned personal freedom legally, which was a historic progress. Although the institution system of census register of craftsmen (jiang-ji) was once carried out in the Yuan and the Ming dynasty, it was progressively developed and fixed in the Qing, which made Chinese ancient handicraft production corvee era come to an end. In this long process, the practice of employing craftsmen by the state-run silk-weaving industry in the Song made undeniable contributions.

\section{References}

Cong, Z. (1169), \& E, S. (during A. D. 1241-1251). History of Lin'an in the Southern Song Dynasty History of Lin'an (1983 ed.). Hangzhou: Zhejiang Acient Books Publishing House.

Cun, W. (1023-1101), Zhao, Z. (1047-1107), \& Dechu, L. (?-after1080). The treaties on the nine regions during the Yuanfeng (A.D.1078-1085) period (1984, congshu jicheng xinbian ed.). Taibei: Xin Wen Feng Publishing Co, Ltd.

DongSheng, X. (2012). Study of the Handicraft Industry Organization of Song Dyansty. Beijing: China Central People Press House.

Duanlin, M. (A. D. 1314). General history of institutions and critical examination of documents (1986 ed.). Beijing: Zhonghua Book Company.

Jinmin, F. (1990). Study of Comparison between the production capacity in the Ming and Qing Dynasty-as a discussion with Mr. Shen Zuwei. History review, (4), 59-60.

Pingsheng, L., \& Jinfang, G. (2014). Analysis on the Urbanization and Classes of Cities of the Southern Song Dynasty. Journal of Sichuan Normal University( Social Sciences Edition), (6), 133-142.

Song, X. (during A. D. 1796-1820). A Draft Version of the Important Documents of the Song (1957, Congshu jicheng chubian, ed.). Beijing: Zhonghua Book Company.

Tao, L. (during A. D. 1029-1102). The submission of a report on ten events to the emperor after mission accomplished (1936, Congshu jicheng chubian, ed.). Shanghai: Commercial Press.

Tuo, T. (A. D. 1346). History of the Song (1977 ed.). Beijing: Zhonghua Book Company.

Xinchuan, L. (ca. 1261). Record of Important Affairs since the Beginning of the Jianyan (1127-1130) Period (1985, Congshu jicheng chubian, ed.). Beijing: Zhonghua Book Company.

Xuanping, Y., \& Feng, Z. (2009). China Silk Culture History. Shandong fine arts publishing house.

You, L. (during A.D.1195-1200). The notes of Laoxue'an (1984, Congshu jicheng xinbian, ed.). Taibein Wen 
Feng Publishing Co, Ltd.

Yufeng, G. (2012). Study of Wage-labor of Handicraft Industry in the Song Dynasty (Master degree thesis). Xi'an, Shanxi Normal University.

Zheng, K. (the Southern Song Dynasty). (1985). Turtle mirror for sentence (Congshu jicheng chubian ed.). Beijing: Zhonghua Book Company.

Zhu, F. (the Yuan Dynasty). Treatise on Shu Brocade (Congshujichengchubian, 1985). Beijing: Zhonghua Book Company.

Zimu, W. (ca. 1274). Dreaming of the former capital (1984, Jingyin Wenyuan'ge siku quanshu, ed.). Taibei: Commericial Press Taiwan.

\section{Copyrights}

Copyright for this article is retained by the author(s), with first publication rights granted to the journal.

This is an open-access article distributed under the terms and conditions of the Creative Commons Attribution license (http://creativecommons.org/licenses/by/3.0/). 